\title{
Occupational asthma in maritime environments:
}

\section{an update}

\author{
David Lucas $^{1}$, Brice Lodde ${ }^{2}$, Jørgen Riis Jepsen ${ }^{3}$, Jean-Dominique Dewitte ${ }^{4}$, Dominique Jegaden ${ }^{2}$ \\ ${ }^{1}$ Occupational Medical Service of Iroise, Brest, France \\ ${ }^{2}$ Department of Occupational Health, University of Brest, Brest, France \\ ${ }^{3}$ University of Southern Denmark, Esbjerg, Denmark \\ ${ }^{4}$ Occupational Medicine, University of Brest, Brest, France
}

\begin{abstract}
In 2006 we published our first review based on the available literature on occupational asthma in maritime environments in the "International Maritime Health" journal. Since then, we have obtained a great deal of new knowledge on asthma in seafood workers and fishermen and on the impact of exposures from sulphites preservatives, container fumigants etc. in maritime workers. This review aims to provide an update of the current knowledge base about occupational asthma in a maritime context and to provide recommendations regarding medical surveillance of workers at risk.
\end{abstract}

(Int Marit Health 2016; 67, 3: 144-152)

Key words: occupational asthma, maritime environments, review

\section{INTRODUCTION}

In 2006, we published a specific article on occupational asthma $(\mathrm{OA})$ in maritime environments [1]. Since then, additional knowledge has emerged and a number of articles on risk factors, pathophysiological mechanisms and preventive options have been published on the subject. In recent reviews on occupational respiratory diseases in the field of maritime environment published in the literature, a big part of the articles deal with the onset of allergy [2-4]. We thought that an update specifically for maritime physicians could be relevant to publish. Asthma affects $5-10 \%$ of the general population in the developed countries and $9-25 \%$ of asthma in adults is regarded as due to occupational factors $[5,6]$.

The maritime environment is characterised by the variety of products to which workers in the different trades in the whole maritime industry (merchant navy, fishing and fish processing industry, and other harbour industries) are exposed.

In 2010, the Food and Agriculture Organisation estimated that more than 45 million people worldwide were directly involved in fishery and aquaculture production and that 142 million tons of seafood were produced per year [3]. Occupational asthma is the most frequently related respiratory disease reported in the seafood industry [4].
From the International Chamber of Shipping, the worldwide population of seafarers serving on internationally trading merchant ships is estimated to be in the order of 466,000 officers and 721,000 ratings (http://www. ics-shipping.org/shipping-facts/shipping-and-world-trade/ number-and-nationality-of-world's-seafarers).

Like in 2006, we made a systematic research in the scientific literature and our personal cases.

Work-related asthma includes $\mathrm{OA}$ and work-aggravated asthma. Occupational asthma can be immunoglobulin $\mathrm{E}$ (IgE)-mediated, have an unknown pathophysiological mechanism or be irritant OA which again consists of reactive airways dysfunction syndrome (RADS), not-so-sudden onset asthma, or low-dose irritant asthma [7].

\section{EPIDEMIOLOGY}

\section{ASTHMA DUE TO SEA PRODUCTS}

The dominant aetiological factors for $O A$ are seafood with higher prevalences associated with exposure to arthropods (crab and shrimp) than to molluscs and fish. Most $\mathrm{OA}$ to those exposures are IgE-mediated subsequent to sensitisation to the protein content in sea products [1]. In some cases, biological agents such as endotoxins, dinofla- 
gellates associated with seafood or agents used in seafood preparation, could cause OA. We deal with the mechanisms in the pathophysiology chapter.

Studies and case reports of OA in maritime environments are summarised in Table 1.

\section{CRUSTACEANS}

Exposure to crustaceans, and especially snow-crab, are the most studied aetiologies. Occupational asthma due to snow-crab (Chionoecetes opilio) was firstly published by Cartier et al. in 1984 [8], IgE sensitisation in 1986 [9] and improved spirometry, hyperreactivity and specific immunoglobulin G (IgG) after cessation of exposure in 1998 by Malo et al. [10]. The detection of snow-crab antigens in air samples was reported in 1997 [11]. In 1994, Endelman [12] already reported a significant rate ( $70 \%$ ) of asthma-like symptoms on processing personal on a fishing boat. More recently, Beaudet et al. [13] found the prevalence of $O A$ in $4-6 \%$ of fishermen from 5 crab-processing vessels. In 2 studies of a population of 303 and 215 Canadian snow-crab processing plant workers, respectively, the prevalence of OA was $16 \%[14,15]$. In a case reviews of the Washington telemedicine service, we published 4 cases of probable snow-crab OA in fishermen [16].

King crabs (Paralithodes camtschaticus) and common crabs (Cancer irroratus) are the two other identified species of crab that has been linked with $\mathrm{OA}$, with prevalences of $9 \%$ and $7 \%$, respectively $[14,17]$.

For crustaceans, a high prevalence of OA due to prawn (Nephrops norvegicus) has been found in process-workers [18]. A lower rate was shown for shrimps (Gammarus et Artemia salina) in 1 study [19], and in case reports in processing workers [20] and in aquaculture technician [21]. Case reports have shown that sensitisation to lobster (Homarus vulgaris et americanus) was mediated through cooking steams $[22,23]$.

\section{MOLLUSCS}

Asthma has also been linked to exposure to bivalves. A prevalence of OA from $20 \%$ to $23 \%$ has been recorded for workers who opened mussels (Perna canaliculus) [24] and a prevalence of $2 \%$ among clam processing workers $[25,26]$ and scallops (Pecten maximus) in restaurant workers $[27,28]$.

Tomaszunas et al. [29] described an asthma incidence of $1 \%$ per year related to exposure to cuttlefish in Polish fishermen. Another case report of OA due to octopus particles has been more recently published for a woman and a man, who were working in seafood factories [30]. For squid (Loligo vulgaris) a case-report described $\mathrm{OA}$, rhinitis and contact urticaria in a man who were working in a frozen-seafood company and in 2 French cooks [31, 32].
Most $\mathrm{OA}$ related to fish are case-reports of sensitisation secondary to inhalation of wet aerosols in fish processing workers and fishmongers, but no case has been described in fishermen [33].

Occupational asthmatic reactions to salmon have been demonstrated with prevalence of $8 \%$ among automated salmon processing workers [34]. In a study including 70 workers of a Norwegian salmon-processing company, wheezing was noted in $5.7 \%$ on Mondays, and $7.1 \%$ of workers have been diagnosed with asthma [35]. In a closed study, 3 cases of $O A$ to salmon were found in a population of 26 salmon-processing workers [36]. Sole, hake, plaice, cod, herring, pilchard, anchovy, swordfish, sole, pomfret, yellowfin, shark and tuna exposure have been related to $O A$ $[2,33]$. The link between trout exposure and $O A$ is unclear [37]. New cases of OA caused by turbot in 3 Spanish fishfarm workers have been published in 2010 [38]. Two epidemiological studies underline the variation in prevalence of work-related symptoms of $\mathrm{OA}$ in fish-processing industries with $1.8 \%$ in South Africa and $42.8 \%$ in Norway $[39,40]$.

\section{WORMS}

Several studies have indicated the parasite Anisakis simplex that infects fish in a larval stage as an aetiology for asthma [41-43]. The first symptoms for the diagnosis of an infection by this parasite are mainly gastro-intestinal ones. An Italian study published in 2000 found sensitivity to Anisakis in $50 \%$ of fishermen versus $0 \%$ in control subjects [44]. Some asthma cases were also recorded during exposure to larva of Chironomus thummi thummi, which is used as baits and food for tropical fish [45], as well as to mosquito larva (Echinodorus plasmosus), which can be found in aquariums [46].

\section{OTHER SEA PRODUCTS}

Nine per cent of Japanese spiny lobster fishermen presented asthma related to a coral species (Dendronephthya nipponica) [47]. Other species have also been associated with asthma, such as the marine sponge Dysidea herbacea, and an invertebrate from the Ascidiacea class living on oyster shells (Styela plicata - better known under the name of Hoya) that has caused an asthma prevalence of $29 \%$ in a population of oyster-workers $[48,49]$. A case of asthma due to seaweed in a thalassotherapist was published more recently [50].

\section{ADDITIVES AND TOXINS}

Preservatives used in fish and seafood processing may also cause OA. Sodium metabisulphite is a chemical preservative used during fishing for processing of fish and crustaceans. Case reports of OA due to sodium metabisulphite have been described in fishermen (lobster fisherman, 
Table 1. Case-reports and studies on occupational asthma in maritime environments

\begin{tabular}{|c|c|c|c|c|c|c|c|c|}
\hline Agent & Workplace & REF & $\begin{array}{l}\text { Number } \\
\text { of } \\
\text { subjects }\end{array}$ & $\begin{array}{l}\text { Prevalence } \\
(\%)\end{array}$ & $\begin{array}{l}\text { Cutaneous } \\
(\%+)\end{array}$ & $\begin{array}{l}\text { Other immunologi- } \\
\text { cal test }(\%+)\end{array}$ & $\begin{array}{l}\text { Bronchial } \\
\text { challenge } \\
(\%+)\end{array}$ & Other \\
\hline \multicolumn{9}{|l|}{ Crabs } \\
\hline King crab & Processors & $14 \mathrm{es}$ & 186 & 13 & $\begin{array}{l}60 \% \text { of } 15 \\
\text { workers }\end{array}$ & $\begin{array}{l}\text { Precipitins } 60 \% \\
\text { of the } 15 \text { workers }\end{array}$ & ND & Spirometry \\
\hline \multirow[t]{6}{*}{ Snow crab } & Processors & 8 es & 303 & 16 & $22 \%$ & ND & $72 \%$ & $\begin{array}{l}\text { Peak-flow of } \\
6 \text { tests }\end{array}$ \\
\hline & Processors & 67 es & 825 & 5.5 & ND & ND & ND & ND \\
\hline & Processors & 15 es & 215 & 15.8 & $+18.3 \%$ & $+\lg E 14.3 \%$ & ND & PEF \\
\hline & On vessels & 59 es & 51 & $U$ & $\begin{array}{l}43 \% \text { crab blood } \\
\text { symptomatic } \\
\text { workers }\end{array}$ & ND & ND & Spirometry \\
\hline & Processors & 67 es & 107 & 19 & ND & RAST: $6-8 \%$ & ND & ND \\
\hline & Processors & 68 es & 205 & $9-50$ & $15-50 \%$ & RAST & ND & ND \\
\hline Common crab & Processors & $17 \mathrm{cr}$ & 29 & 7 & $\begin{array}{l}25 \% \text { workers } \\
\text { with symptoms }\end{array}$ & ND & $14 \%$ of 14 & $\begin{array}{l}\text { Spirometry } \\
\text { Methacholine }\end{array}$ \\
\hline \multirow[t]{2}{*}{ Several species } & On vessels & 13 es & 82 & $4-6$ & ND & ND & ND & ND \\
\hline & Processors & $69 \mathrm{cr}$ & 46 & $\begin{array}{l}\text { Incidence } \\
2 \% / \text { month }\end{array}$ & ND & ND & ND & ND \\
\hline Lobsters & Cook & $23 \mathrm{cr}$ & 1 & ND & $\begin{array}{l}\text { + lobster, } \\
\text { oyster, clams }\end{array}$ & ND & + & Spirometry \\
\hline \multirow[t]{2}{*}{$\begin{array}{l}\text { Lobsters + } \\
\text { shrimps }\end{array}$} & Fishmonger & $19 \mathrm{cr}$ & 1 & $U$ & $\begin{array}{l}+ \text { lobster, } \\
\text { prawn, crab }\end{array}$ & $\begin{array}{l}\text { RAST + lobster, } \\
\text { shrimp }\end{array}$ & $\begin{array}{l}\text { + lobster, } \\
\text { shrimp }\end{array}$ & ND \\
\hline & Cook & $22 \mathrm{cr}$ & 1 & U & + lobster & ND & - & ND \\
\hline Prawns & Processors & 18 es & 50 & 36 & Workers & $\begin{array}{l}\text { RAST } 16 \% \\
\text { Precipitins } 62 \% \\
\text { with symptoms }\end{array}$ & $\begin{array}{l}100 \% \text { of } \\
2 \text { tests }\end{array}$ & ND \\
\hline \multicolumn{9}{|l|}{ Shrimps } \\
\hline \multirow[t]{2}{*}{ Shrimps } & $\begin{array}{l}\text { Laboratory } \\
\text { technician }\end{array}$ & $21 \mathrm{cr}$ & 1 & $U$ & + shrimp & $\begin{array}{l}\text { RAST + shrimp, } \\
\text { crab }\end{array}$ & + shrimp & ND \\
\hline & $\begin{array}{l}\text { Plant } \\
\text { fish-food }\end{array}$ & $20 \mathrm{cr}$ & 1 & ND & + gammarus & ND & + shrimp & Spirometry \\
\hline \multirow[t]{2}{*}{ Gammarus } & Processors & $54 \mathrm{cr}$ & 2 & & + crab, shrimp & RAST + shrimp & + shrimp & \\
\hline & Processors & 40 es & 132 & $>24$ WRAS & + shrimp $20.3 \%$ & & & \\
\hline $\begin{array}{l}\text { Shrimps and } \\
\text { clams }\end{array}$ & Processors & 25 es & 56 & $\begin{array}{l}\text { Shrimp: } 5 \\
\text { Clam: } 2\end{array}$ & $\begin{array}{l}\text { + shrimp 16\% } \\
+ \text { clam } 7 \% \\
\text { Of }\end{array}$ & $\begin{array}{l}\text { RAST + } \\
\text { Shrimp: } 14-16 \% \\
\text { Clam: } 5-7 \% \\
\text { ll workers }\end{array}$ & 67 (3 tests) & Methacholine \\
\hline Clam & $\begin{array}{l}\text { Medical } \\
\text { student }\end{array}$ & 26 es & 1 & $U$ & + & ND & + & ND \\
\hline Mussels (?) & $\begin{array}{l}\text { Mussels } \\
\text { openers }\end{array}$ & 24 es & 224 & $20-23$ & ND & ND & ND & Peak-flow \\
\hline Scallops & Cook & $27 \mathrm{cr}$ & 1 & $U$ & + & RAST + & + & ND \\
\hline Cuttlefish & Fishermen & 29 es & 66 & $\begin{array}{l}\text { Incidence } \\
\text { 1\%/year }\end{array}$ & ND & ND & ND & ND \\
\hline Squid & $\begin{array}{l}\text { Frozen- } \\
\text {-seafood }\end{array}$ & $31 \mathrm{cr}$ & 1 & $U$ & ND & ND & ND & ND \\
\hline Abalone & Fisherman & $27 \mathrm{cr}$ & 1 & U & ND & ND & + & ND \\
\hline
\end{tabular}


Table 1. (cont.) Case-reports and studies on occupational asthma in maritime environments

\begin{tabular}{|c|c|c|c|c|c|c|c|c|}
\hline Agent & Workplace & REF & $\begin{array}{l}\text { Number } \\
\text { of } \\
\text { subjects }\end{array}$ & $\begin{array}{l}\text { Prevalence } \\
(\%)\end{array}$ & $\begin{array}{l}\text { Cutaneous } \\
(\%+)\end{array}$ & $\begin{array}{l}\text { Other immunologi- } \\
\text { cal test }(\%+)\end{array}$ & $\begin{array}{l}\text { Bronchial } \\
\text { challenge } \\
(\%+)\end{array}$ & Other \\
\hline \multicolumn{9}{|l|}{ Fishes } \\
\hline \multirow[t]{6}{*}{ Several species } & \multirow{2}{*}{$\begin{array}{l}\text { Plant } \\
\text { workers }\end{array}$} & \multirow[t]{2}{*}{33 es } & \multirow[t]{2}{*}{51} & \multirow[t]{2}{*}{2} & $23 \%$ & \multirow{2}{*}{$\begin{array}{l}\text { IgE tot } \\
\text { ardine, salmon, herring }\end{array}$} & \multirow{2}{*}{ ND } & \multirow[t]{2}{*}{ Nasal test } \\
\hline & & & & & Sole, cod, tuna, s & & & \\
\hline & $\begin{array}{l}\text { Fish } \\
\text { processors }\end{array}$ & 39 es & 594 & 1.8 & $+6 \%$ & $\begin{array}{l}\text { IgE }+ \text { anchovy }(5 / 15) \\
+ \text { pilchard }(4 / 15)\end{array}$ & ND & Methacholine \\
\hline & Fishmongers & 70 es & 64 & 2/64 WRAS & $\begin{array}{l}\text { + shrimp } \\
12.5 \% \text {, spiny } \\
\text { lobster } 10.9 \% \text {, } \\
\text { crab } 3.1 \%\end{array}$ & & ND & Spirometry \\
\hline & $\begin{array}{l}\text { Smoking fish } \\
\text { plant }\end{array}$ & $30 \mathrm{cr}$ & 1 & $U$ & $\begin{array}{l}\text { + tuna, salmon, } \\
\text { sole }\end{array}$ & & $\begin{array}{l}\text { + raw tuna, } \\
\text { sole, } \\
\text { salmon }\end{array}$ & ND \\
\hline & $\begin{array}{l}\text { Fish } \\
\text { processors }\end{array}$ & 40 es & 387 & $\begin{array}{l}>14.1 \% \\
\text { WRAS }\end{array}$ & ND & - salmon & ND & ND \\
\hline \multirow[t]{4}{*}{ Salmon } & $\begin{array}{l}\text { Plant } \\
\text { workers }\end{array}$ & 34 es & 291 & $8 \%$ & ND & RAST: 9\% & ND & Spirometry \\
\hline & $\begin{array}{l}\text { Frozen- } \\
\text {-fishes }\end{array}$ & $1 \mathrm{cr}$ & $U$ & $\begin{array}{l}\text { + raw salm- } \\
\text { on, trout, } \\
\text { sardine }\end{array}$ & & ND & + salmon & ND \\
\hline & Processors & 40 es & 211 & $\begin{array}{l}>13.2 \\
\text { WRAS }\end{array}$ & ND & $+\operatorname{cod} 2.7 \%$ & ND & ND \\
\hline & Processors & 35 es & 70 & 7.1 & ND & IgE + salmon $2.9 \%$ & ND & Spirometry \\
\hline Turbot & $\begin{array}{l}\text { Fish-farm } \\
\text { workers }\end{array}$ & $38 \mathrm{cr}$ & 3 & U & $\begin{array}{l}\text { + turbot, cod, } \\
\text { sardine, hake }\end{array}$ & IgE + turbot & $\begin{array}{l}+ \text { turbot } \\
3 \text { cases }\end{array}$ & PEF \\
\hline Trout & Trout-fileting & 37 es & 8 & $U$ & ND & RAST: $100 \%$ & ND & ND \\
\hline \multicolumn{9}{|l|}{ Anisakis simplex } \\
\hline & Chicken farm & $41 \mathrm{cr}$ & 1 & $U$ & + & RAST + & + & ND \\
\hline & Fishmonger & $41 \mathrm{cr}$ & 1 & $U$ & + & RAST + & + & $U$ \\
\hline & Frozen fish & $42 \mathrm{cr}$ & 1 & U & + & Immunoblot & ND & Spirometry \\
\hline & Cook & $45 \mathrm{cr}$ & 1 & $U$ & + & RAST + & + & Methacholine \\
\hline \multicolumn{9}{|l|}{ Worms } \\
\hline $\begin{array}{l}\text { Several species } \\
\text { Galleria } \\
\text { mellonella } \\
\text { Calliphora } \\
\text { vomitoria } \\
\text { Tenebrio molitor }\end{array}$ & Worms farm & 50 es & & 4 & $32 \%+$ & $\begin{array}{l}\text { RAST: } 71 \% \text { on } \\
17 \text { workers }\end{array}$ & ND & ND \\
\hline $\begin{array}{l}\text { Lucilia caesar } \\
\text { Galleria } \\
\text { mellonella } \\
\text { Tenebrio molitor }\end{array}$ & $\begin{array}{l}\text { Fishmonger } \\
\text { Worms farm }\end{array}$ & $14 \mathrm{cr}$ & & U & $\begin{array}{l}13 \text { test } \\
92 \% \text { Lucilia } \\
\text { caesar } \\
\text { 15\% Galleria } \\
\text { mellonella } \\
23 \% \text { Tenebrio } \\
\text { molitor }\end{array}$ & $\begin{array}{l}\text { RAST } 13 \text { tests } \\
\text { 92\% Lucilia } \\
\text { caesar } \\
23 \% \text { Galleria } \\
\text { mellonella } \\
7 \% \text { Tenebrio } \\
\text { molitor }\end{array}$ & ND & $\begin{array}{l}\text { Spirometry } \\
\text { Methacholine }\end{array}$ \\
\hline $\begin{array}{l}\text { Lombricus } \\
\text { terrestris }\end{array}$ & Fishmonger & $1 \mathrm{cr}$ & & U & + & RAST & ND & ND \\
\hline Eisenia foetida & Fishmonger & $1 \mathrm{cr}$ & & U & $\begin{array}{l}\text { + Eisenia } \\
\text { foetida } \\
\text { - Tenebrio } \\
\text { molitor }\end{array}$ & RAST & ND & Nasal test \\
\hline
\end{tabular}


Table 1. (cont.) Case-reports and studies on occupational asthma in maritime environments

\begin{tabular}{|c|c|c|c|c|c|c|c|c|}
\hline Agent & Workplace & REF & $\begin{array}{l}\text { Number } \\
\text { of } \\
\text { subjects }\end{array}$ & $\begin{array}{l}\text { Prevalence } \\
\text { (\%) }\end{array}$ & $\begin{array}{l}\text { Cutaneous } \\
(\%+)\end{array}$ & $\begin{array}{l}\text { Other immunologi- } \\
\text { cal test }(\%+)\end{array}$ & $\begin{array}{l}\text { Bronchial } \\
\text { challenge } \\
(\%+)\end{array}$ & Other \\
\hline $\begin{array}{l}\text { Marphysa } \\
\text { sanguinea }\end{array}$ & Fishmonger & $1 \mathrm{cr}$ & & U & $\begin{array}{l}\text { + Marphysa } \\
\text { sanguinea } \\
\text { - Lumbricus ter- } \\
\text { restris }\end{array}$ & $\begin{array}{l}\text { RAST histamine } \\
\text { release }\end{array}$ & ND & Nasal test \\
\hline \multicolumn{9}{|c|}{ Marine sponges } \\
\hline $\begin{array}{l}\text { Dysidea } \\
\text { herbacea }\end{array}$ & $\begin{array}{l}\text { Laboratory } \\
\text { technician }\end{array}$ & $48 \mathrm{cr}$ & 1 & U & ND & $\begin{array}{l}\text { RAST } \\
\text { Dysidea herbacea } \\
6 \text { species of sponges } \\
2 \text { coral species }\end{array}$ & ND & ND \\
\hline Coral & $\begin{array}{l}\text { Spiny lobster } \\
\text { fishermen }\end{array}$ & 47 es & 72 & $9 \%$ & $\begin{array}{l}100 \% \text { on } \\
2 \text { test }\end{array}$ & $\begin{array}{l}\text { RAST } 50 \% \\
\text { coral and spiny lob- } \\
\text { ster }\end{array}$ & ND & ND \\
\hline Hoya & $\begin{array}{l}\text { Oyster aqu- } \\
\text { aculturists }\end{array}$ & 49 es & 1413 & $29 \%$ & $\begin{array}{l}82 \% \text { on } \\
511 \text { test }\end{array}$ & RAST 89\% & $\begin{array}{l}82 \% \\
17 \text { test }\end{array}$ & ND \\
\hline Seaweed & $\begin{array}{l}\text { Thalassothe- } \\
\text { rapist }\end{array}$ & $50 \mathrm{cr}$ & 1 & U & ND & ND & + & ND \\
\hline
\end{tabular}

$\mathrm{cr}$ - case report; es - epidemiological study; IgE - immunoglobulin E; Methacholine - methacholine test with spirometry; ND - not done; RAST - radio-allergosorbent test; U - unknown; WRAS - work-related asthmatic symptoms; REF - number of reference; PEF - peak expiratory flow

trawlerman, and prawn fishermen) [51-53]. Two cases have been recently published in France in shrimp-processing workers [54]. Even "natural” additives such as garlic, mustard and anise, which are often used in fishery industry, are well known OA triggers [55]. Marine toxins like histamine or bacterial toxins found in seafood are other agents with the potential to cause respiratory diseases $[2,56]$. Another risk was cockroach contact. Cockroaches are detected ashore as well as on board ships all over the world. In 2005, in Hamburg, $10.6 \%$ of ocean-going ships investigated were infested by cockroaches that are well-known causes of airway allergy [57].

\section{PATHOPHYSIOLOGY}

In the maritime world, and more specifically for seafood, $\mathrm{OA}$ is mostly immunologic and IgE-mediated with sensitisation to an antigen present in marine organisms or to an associated agent present in the matrix.

Since we published our first review in 2006, a number of crustaceans, fishes and other seafood allergens have been identified with sensitisation through ingestion. By contrast, for inhalation, few new findings have been published. The major allergenic proteins found in those studies are high molecular weight proteins like tropomysosin and arginin kinase for crustaceans and parvalbumin for fish [2]. The pathophysiology of OA from seafood stems from inhalation and immune sensitisation to those proteins from, e.g. meat, endolymph, exoskeleton, or blood, which is aerosolised during work processes [55]. The occurrence of cross-reactivity may cause allergic reactions to multiple species of seafood. Crustaceans are reported to be more allergenic than fish [4].
Recently, it was also demonstrated that digestive enzymes like trypsin from visceral contents in salmon, herring and king crab can stimulate inflammatory processes in the airways [2]. For associated agents with respiratory actions, we have earlier described aetiologies like sea-squid and anisakis, but some marine toxins (histamine, endotoxin), chemical additives (sodium metabisulphite, formaldehyde), spices and gases products during decomposition like hydrogen sulphide can also be responsible of acute respiratory diseases $[2,58]$.

Fishermen with asthma due to exposure to sodium metabisulphites have negative skin prick tests and specific lgE tests, while positive bronchial challenge tests and specific bronchial challenge tests proves the relation to sodium metabisulphite [51-53]. Similar findings apply to asthma in shrimp-processing workers, in which the radio-allergosorbent test (RAST) levels for common allergens and sodium metabisulphite were negative while peak-flow monitoring and specific bronchial challenge are positive [54]. These findings lead to the conclusion of irritative $\mathrm{OA}$, but it is well-known that exposure to respiratory irritant agents in the workplace can cause work-aggravated asthma and be a risk factor of developing OA. Sodium metabisulphite is a specific example in maritime environments for exposure to an irritant agent [3]. A case-report published in 2014 by Uriarte et al. [59] described the case of a 38-year-old woman who had been working in a Spanish seafood-packing factory. They performed two specific inhalations, one with only sodium metabisulphite and the other with raw squid. Both of them were positive with late asthmatic responses. Sensitisation to shrimp, octopus, and fish was confirmed by skin test and 
specific IgE, but unfortunately nothing was mentioned about prick or specific lgE testing for sodium metabisulphite.

Another particularity of seafood workers and fishermen is endotoxin exposure at work. In studies of crab processing, the total and respirable concentration of airborne endotoxin was 32.6 (Endotoxin Unit/ $/ \mathrm{m}^{3}\left[\mathrm{EU} / \mathrm{m}^{3}\right]$ ) and $15.6 \mathrm{EU} / \mathrm{m}^{3}$ [14]. More recently, levels between $5.8 \mathrm{EU} / \mathrm{m}^{3}$ and $29.9 \mathrm{EU} / \mathrm{m}^{3}$ have been reported in shrimp processors $[3,40]$. Fish processors are also exposed to endotoxins with levels of airborne concentrations in the range between $6.8 \mathrm{EU} / \mathrm{m}^{3}$ and $136 \mathrm{EU} / \mathrm{m}^{3}$ [2]. The role of exposures to endotoxins in $\mathrm{OA}$ is not yet well-characterised for work-related respiratory symptoms. Recently, Shiryaeva et al. [35] found levels of endotoxin of $29 \mathrm{EU} / \mathrm{m}^{3}$ in salmon-processing plants and more specifically, a very high level of airborne endotoxin was found in water from the transport tank (779 EU/mL) [36].

Recent studies underline the presence of high levels of endotoxin in several plants, and in a salmon-processing plant high atmospheric levels of mould spores (Penicillium notatum, Aspergillus aspergillus and Cladosporium herbarum) were found when filleting fresh salmon [36].

Also in a Croatian study, high levels of dust mites, and especially Pyroglyphid mites, have been measured in bed samples of fishing boats [60]. Moulds may also be responsible of respiratory diseases.

In Norwegian salmon-processing workers, Shiryaeva et al. [35] found a change in respiratory symptoms and pulmonary test with significant associations with total Protein levels on Mondays only. Associated with the healthy worker effect a tolerance effect is suggested for the first time in seafood workers and needs further investigations [35].

Typically, wet aerosols encountered in the processing of fresh seafood products constitute the exposure and subsequent sensitisation. However, exposure may also occur by vaporised allergens inhaled during the cooking of crab and lobster [8, 11-14, 17, 22, 23].

Atmospheric allergen concentration is the major professional risk factor responsible for the development of $\mathrm{OA}$ in the commercial fishing industry [16]. Most high-risk work stations for snow crab workers are boiling, butchering stations, body leg stations; concentrations of allergens in atmosphere in those stations on vessels have been measured as $1,657 \mathrm{ng} / \mathrm{m}^{3}, 7,443 \mathrm{ng} / \mathrm{m}^{3}$ and $5,061 \mathrm{ng} / \mathrm{m}^{3}$, respectively $[9,61,62]$. Although, only $25 \%$ of snow crab plant employees work at butchering stations, these stations account for $70 \%$ of asthma cases thus highlighting the importance of atmospheric allergen concentration [13]. In fish-processing, a total inhalable concentration of allergen of $5,100 \mu \mathrm{g} / \mathrm{m}^{3}$ has been shown [2].

Some physical factors, like cold air, high physical activity, hypertonic saline aerosols, may trigger respiratory symptoms [63].
Atopy is the most important host risk factor for OA related to work with crabs, prawns, cuttlefish, pilchard and anchovy, while smoking is a risk factor for asthma caused by work with prawns, crabs, pilchard, anchovy and salmon [2].

For others exposures, the influence of atopy and smoking is unknown because our knowledge of these is based on publications with few cases related to the maritime environment.

\section{ASTHMA DUE TO PRODUCTS TRANSPORTED BY VESSELS}

Since 2006 and the publication of our first review [1], limited research relating to aetiologies of $\mathrm{OA}$ in the maritime environment have been published. We suggest you to read the paper published in 2006 and the exhaustive review, which was recently published by Baur and Bakehe [7] on other allergens causing $\mathrm{OA}$ and irritant-induced $\mathrm{OA}$.

In a study of silo port workers we did not found cases of OA but $37.5 \%$ had occupational rhinitis and $50 \%$ of workers were sensitised to grain [64].

Baur et al. [65] have described chemical exposures and associated health effects of fumigants in containers. Fumigants like bromomethane, hydrogen phosphide, 1,2-dichloroethane, trichloronitromethane and ethylene oxide and gases released from goods transported by containers like formaldehyde, benzene, and toluene have been well documented in freight container air samples. Occupational asthma from formaldehyde has been reported in industry and laboratory work as well as in port workers and seafarers, e.g. the manufacture of fish meal requires the use of formaldehyde, which may spread to the work environment and the surroundings [7].

Bromomethane, hydrogen phosphide, 1,2-dichloroethane, and chloropicrin are irritants for the respiratory tract and similar to sodium metabisulphite can cause work-aggravated asthma [66-68].

After banning the use of tributyltin, new chemical products have been developed for antifouling paints. Some of these are known to be agents that can cause OA. The paints may contain high concentration of copper or lower concentrations of zinc or aluminium as well as chlorothalonil [68] for fungicidal and algicidal actions. Isocyanates, epoxy resins and other resins are also used in coating paints [7].

\section{RECOMMENDATIONS FOR PREVENTION, TREATMENT AND MEDICAL SURVEILLANCE}

In a population of seafarers and workers in seafood processing, we must be careful with respect to exposure to agents that can cause $O A$.

At the first examination, we have to search individual risk factors of OA such as atopy, asthma, smoking and a history of ingestion-related allergy with seafood. It is estimated 
Table 2. Recommendations for medical survey

\begin{tabular}{|c|c|c|c|}
\hline Examination & Questionnaire & Clinical examination & Paraclinical examinations \\
\hline $\begin{array}{l}\text { First } \\
\text { examination }\end{array}$ & $\begin{array}{l}\text { Atopy } \\
\text { Asthma } \\
\text { Smoking habits } \\
\text { Ingestion-related allergy } \\
\text { with seafood and fishes }\end{array}$ & $\begin{array}{l}\text { Dermatological } \\
\text { Otorhinolaryngological } \\
\text { Pulmonary }\end{array}$ & $\begin{array}{l}\text { Spirometry if signs of allergy: } \\
\text { - } \text { prick tests (common and occupational agents) } \\
\text { - } \text { RAST with total IgE } \\
\text { methacholine respiratory test }\end{array}$ \\
\hline $\begin{array}{l}\text { Regular } \\
\text { examination }\end{array}$ & $\begin{array}{l}\text { First signs of eczema, } \\
\text { rhinitis or asthma }\end{array}$ & $\begin{array}{l}\text { Signs of eczema, rhinitis } \\
\text { or asthma }\end{array}$ & $\begin{array}{l}\text { Spirometry every } 4 \text { years or if signs of allergy: } \\
\text { - } \text { prick tests (common and occupational agents) } \\
\text { - } \text { RAST with total lgE } \\
\text { - methacholine respiratory test }\end{array}$ \\
\hline
\end{tabular}

that $7 \%$ of workers with ingestion-related seafood allergy develop asthma symptoms after exposure to respiratory seafood allergens [39].

Previous and actual dermatological and upper and lower airway symptoms and signs including rhinitis and conjunctivitis must be noted at the medical examination.

For paraclinical tests, it's useful to have an initial spirometry or peak expiratory flow assessment.

The medical surveillance should to detect the first symptoms or clinical signs of OA or rhinitis. If workers have respiratory symptoms, a diagnostic scheme should be done with further immunological tests (prick-tests, standard and specific, RAST and total IgE and respiratory tests with methacholine test, and, if necessary to confirm the aetiology, a challenge test). It has been demonstrated, that the prognosis of OA does not only depend on the duration of exposure and level of exposure, particularly after onset of symptoms (summarised in Table 2).

Treatment is a combination of medications and reduced or removed exposure and, if necessary, work withdrawal. Malo have demonstrated that in a population of snow-crab processing workers, following work-withdrawal, a plateau of improvement was reached after a mean of 1 year for spirometry and after 2 years for non-specific bronchial hyperreactivity [10].

Studies in Canada and South Africa have shown that the main occupational risk factors are the atmospheric allergen concentration and the exposure dose (duration and level) of the causative substances [1-4]. Gaddie et al. [18] and Douglas et al. [34] illustrated this in prawn- and salmon-processing plants, respectively, with no new cases of $\mathrm{OA}$ and fewer asthma symptoms after reduction of the atmospheric levels of the causing substances. Moreover, Gautrin et al. [15] have shown in 2010 that cumulative exposure to snow crab allergens is positively associated with $\mathrm{OA}$ and allergy in a dose-response manner.

Other environmental factors like humidity level, cold air, and exposure to respiratory irritants are also contained in the prevention scheme.
As demonstrated by Gaddie et al. [18], Orford et al. [14] and Douglas et al. [34] in their studies, the level of atmospheric exposure to is correlated with the development of $\mathrm{OA}$. So, collective prevention by an adequate ventilation to reduce atmospheric concentrations of causative agents is the most relevant and effective action.

\section{CONCLUSIONS}

This up-dated review of the diverse aetiologies of OA in maritime environments underlines the relevance for health services dealing with seafarers, dockers, and employees in the maritime food-processing industry in addressing occupational respiratory, dermatological, and rhinitis symptoms. Most studies have suggested or confirmed an IgE-mediated OA to seafood allergens.

Some studies underline high exposures of environmental allergens like moulds and mites in occupational settings $[59,66]$. However, more knowledge on those professional exposures is needed.

In France, the acknowledgement of asthma as occupational disease has appeared only since 1999 for seafarers. Major studies of OA conducted in seafood workers bring up new and essential findings. But few studies have been conducted in seafarers and fishermen. We need more knowledge about the prevalence and distribution of $\mathrm{OA}$ and the risk factors for $\mathrm{OA}$ in these trades.

\section{REFERENCES}

1. Lucas D, Jegaden D, Lodde B, Arvieux C, Dewitte JD. Occupational asthma in maritime environment. Int Marit Health 2006; 57: 177-187.

2. Jeebhay MF, Cartier A. Seafood workers and respiratory disease: an update. Curr Opin Allergy Clin Immunol 2010; 10: 104-113.

3. Lopata AL, Jeebhay MF. Airborne seafood allergens as a cause of occupational allergy and asthma. Curr Allergy Asthma Rep 2013; 13: $288-297$.

4. Jeebhay MF, Lopata AL. Occupational allergies in seafood-processing workers. Advances in Food and Nutrition research. Elsevier 2012; 66: 47-73.

5. Gautrin D, Newman-Taylor AJ, Nordman H, Malo JL. Controversies in epidemiology of occupational asthma. Eur Respir J 2003; 22: 551-559. 
6. Toren K, Blanc PD. Asthma caused by occupational exposure is common - a systematic analysis of estimate population-attributable fraction. BMC Pulm Med 2009; 9: 7. doi: 10.1186/1471-2466-9-7.

7. Baur X, Bakehe P. Allergens causing occupational asthma: an evidence-based evaluation of the literature. Int Arch Occup Environ Health 2014; 87: 339-363.

8. Cartier A, Malo JL, Forest F et al. Occupational asthma in snow-crab processing workers. J Allergy Clin Immunnol 1984; 74: 261-269.

9. Cartier A, Malo JL, Ghezzo H, McCants M, Lehrer SB. IgE sensitization in snow crab processing workers. J Allergy Clin Immunol 1986; 78: 344-348.

10. Malo JL, Cartier A, Ghezzo H et al. Patterns of improvement in spirometry, bronchial hyperresponsiveness, and specific IgE antibody levels after cessation of exposure in occupational asthma by snowcrab processing. Am Rev Respir Dis 1998; 138: 807-812.

11. Malo JL, Chrétien P, McCants M, Lehrer S. Detection of snow-crab antigens by air sampling of a snow-crab production plant. Clin Exp Allergy 1997; 27: 75-78.

12. Endelman PA. Exposure, assessment and prevalence of asthma among maritime crab processing personal. Paper presented at the American Hygiene Conference and Exposition. Los Angeles 1994.

13. Beaudet N, Brodkin CA, Stover B et al. Crab allergen aboard five crab-processing vessels. AlHA J 2002; 63: 605-609.

14. Orford RR, Wilson JT. Epidemiologic and immunologic studies in process of the king crab. Am J Ind Med 1985; 7: 155-169.

15. Gautrin D, Cartier A, Howse D et al. Occupational asthma and allergy in snow crab-processing in Newfoundland and Labrador. Occup Environ Med 2010; 67: 17-23.

16. Lucas D, Lucas R, Boniface K, Jegaden D, Lodde B, Dewitte JA. Occupational asthma in the commercial fishing industry: a case series and review of the literature. Int Marit Health 2010; 61: 13-16.

17. Cartier A, Hunt B, Weytjens K et al. Occupational asthma to Atlantic rock crab processing workers in Eastern North America. J Allergy Clin Immunol 1999; 103: 179

18. Gaddie J, Legge JS, Reid TMS. Pulmonary hypersensitivity in prawn workers. Lancet 1980; 2: 1350-1353.

19. Lemière C, Desjardins A, Lehrer S, Malo JL. Occupational asthma to lobster and shrimp. Allergy 1996; 51: 272-273.

20. Baur X, Huber H, Chen Z. Asthma to Gammarus shrimp. Allergy 2000; 55: 96.

21. Carino M, Elia G, Molini R, Nuzzaco A, Ambrosi L. Shrimpmeal asthma in the aquaculture industry. Med Lav 1985; 76: 471-475.

22. Burel A, Camus F, Leroyer C, Dewitte JD. Allergies respiratoires dues aux homards chez un cuisinier. 1ères journées thématiques de la Société française de Médecine du Travail Paris - 28/01/95. Arch Mal Prof 1996: 294-296.

23. Prakash C, Patel CP, Cockcroft DW. Occupational asthma caused by exposure to cooking lobster in the work environment: a case report. Ann All 1992; 68: 360-361.

24. Glass WI, Power P, Burt R, Fishwick D, Bradshaw LM, Pearce NE. Work-related respiratory symptoms and lung function in New Zealand mussel openers. AM J Ind Med 1998; 34: 163-168.

25. Desjardins A, Malo JL, L'archevêque J et al. Occupational IgE sensitization and asthma caused by clam and shrimp. J Allergy Clin Immunol 1995; 96: 608-617.

26. Karlin JM. Occupational asthma to clam's liver extract. J Allergy Clin Immunol 1979; 63: 197.

27. Goetz DW, Whisman BA. Occupational asthma in a seafood restaurant worker: cross-reactivity of shrimp and scallops. Ann Allergy Asthma Immunol 2000; 85: 431-433.
28. Barraclough RM, Walker J, Hamilton N, Fishwick D, Curran AD. Sensitization to king scallop (Pectin maximus) and queen scallop (Chlamys opercularis). Occup Med (Lond) 2006; 56: 63-66.

29. Tomaszunas S, Weclawik Z, Lewinski M. Allergic reactions to cuttlefish in deep-sea fishermen. Lancet 1988; 1: 1116-1117.

30. Rosaldo A, Tejedor MA, Benito C, Cardenas R, Gonzales-Mancebo E. Occupational asthma caused by octopus particles. Allergy 2009; 64: 1101-1102.

31. Wiszniewska M, Tymoszuk D, Pas-Wyroslak A et al. Occupational asthma to squid (Loligo vulgaris). Occup Med 2013; 63: 298-300.

32. Tabka F, Choudat D, Vacher JG, Thomas-Alliel S, Martin JC, Conso F. Occupational immediate type squid allergy. Two cases. Rev F All Immunol Clin 1998; 38: 713-715.

33. Droszcz W, Kowalski J, Piotrowska B, Pawlowicz A, Pietruszewska E. Allergy to fish in fish meal factory workers. Int Arch Occup Environ Health 1981; 49: 13-19.

34. Douglas JD, McSharry C, Blaikie L, Morrow T, Miles S, Franklin D. Occupational asthma caused by automated salmon processing. Lancet 1995; 346: 737-740.

35. Shirayeva O, Aasmoe L, Straume B, Heldal KK. Respiratory effects of bioaerosols: Exposure-response study among salmon-processing workers. Am J Ind Med 2014; 57: 276-285.

36. Dahlman-Hoglund A, Renstrom A, Larsson PH, Elsayed S, Andersson E. Salmon allergen exposure, occupational asthma, and respiratory symptoms among salmon processing workers. Am J Ind Med 2012; 55: $624-630$

37. Sherson D, Hansen I, Sisgaard T. Occupationally related respiratory symptoms in trout-processing workers. Allergy 1989; 44: 336-341.

38. Perez Carral C, Martin-Lazaro J, Ledesma A, De la Torre F. Occupational asthma caused by turbot allergy in 3 fish-farm workers. J Investig Allergol Clin Immunol 2010; 20: 349-351.

39. Jeebhay MF, Robins TG, Miller ME et al. Occupational allergy and asthma among salt water fish processing workers. Am J Ind Med 2008; 51:899-910.

40. Bang B, Aasamoe L, Aamodt BH et al. Exposure and airway effects of seafood industry workers in northern Norway. J Occup Environ Med 2005; 47: 482-492.

41. Armentia A, Lombardero M, Callejo A et al. OA by Anisakis simplex. J All Clin Immunol 1998; 102: 831-834.

42. Pulido-Marrero Z, Gonzales-Mancebo E, Alfaya-Arias T et al. Unusual sensitization to Anisakis simplex. Allergy 2000; 55: 586.

43. Scala E, Giani M, Pirrota L et al. Occupational generalised urticaria and allergic airborne asthma due to Anisakis simplex. Eur J Dermatol 2001; 11:249-250.

44. Purello-D’Ambrosio F, Pastorello E, Gangemi S et al. Incidence of sensitivity to Anisakis simplex in a risk population of fishermen/ fishmongers. Ann Allergy Asthma Immunol 2000; 84: 439-444.

45. Baldo A, Liebers V, Hoernstein M, Baur X. Humoral immune response to insect allergen Chit I in aquarists and fish-food factory workers. Allergy 1993; 15: 335-343.

46. Resta O, Foschino-Barbaro MP, Carnimea N, Di Napoli PL, Pavese I, Schino P. Occupational asthma from fish-feed (Echinodorus plasmus larva). Medicina Lavoro 1982; 73: 234-236.

47. Onizuka R, Inoue K, Kamiya H. Red soft coral-induced allergic symptoms observed in spiny lobster fishermen. Aerugi 1990; 39: 339-347.

48. Krilis S, Taylor KM. IgE-mediated acute asthma following inhalation of powdered marine sponge. Clin Allergy 1982; 12: 179-186.

49. Jyo T, Komoto K, Tsuboi T et al. Sea squirt asthma-occupational induced by inhalation of antigens substances contained in Sea squirt body fluid. Allergy Immunology (Leipzig) 1974/75; 20/21: $435-448$. 
50. Boulet LP. Algae-induced occupational asthma in a thalassotherapist. Occup Med 2006; 56: 282-283.

51. Madsen J, Sherson D, Kjoller H, Rasmussen K. Occupational asthma caused by sodium disulphite in Norwegian lobster fishing. Occup Environ Med 2004; 61: 873-874.

52. Steiner M, Scaife A, Semple S, Hulks G, Ayres JG. Sodium metabisulphite induced airways disease in the fishing and fishing-processing industry. Occup Med 2008; 58: 545-550.

53. Pougnet R, Loddé B, Lucas D, Jégaden D, Bell S, Dewitte JD. A case of occupational asthma from metabisulphite in a fisherman. Int Marit Health 2010; 62: 180-184.

54. Millet A, Morel H, Heautot JF, Corre R, Curran Y. Occupational asthma in shrimp-processing industry: what behind all this? Presse Med 2008; 37: 1819-1821. doi 10.1016/j.lpm.2007.10.021.

55. Jeebhay MF, Robins TG, Lehrer SB, Lopata AL. Occupational seafood allergy: a review. Environ Med 2001; 58: 553-562.

56. Macan J, Vucemilović A, Turk R et al. Occupational histamine poisoning by fish flour: a case report. Occup Med (Lond) 2000; 50: 22-24.

57. Oldenburg M, Baur X. Cockroach Infestation on Seagoing Ships. Archives of Environmental \& Occupational Health 2008; 63: 4146. doi: 10.3200/AEOH.63.1.41-46.

58. Kenyon C, Wilcox P, Jeebhay MF. Hydrogen sulphide gas poisoning aboard a fishing trawler: a report of four fishermen. Occup Health Southern Africa 2008; 14: 20-23.

59. Uriarte SA, Fernandez-Nieto M, Arochena L, Saste J. Occupational asthma In seafood manufacturing and food allergy to seafood. J Investig Allergol Clin Immunol 2015; 25: 55-82.
60. Macan J, Kanceljak-Macan B, Mustac M, Milkovic-Kraus S. Analysis of dust samples from urban and rural occupational environments in Croatia. Arh Hig Rada Toksikol 2005; 56: 327-332.

61. Dorsett DS, Sechena R. Artic snow crab-related lung disease. Int J Circumpolar Health 1998, 57 (suppl. 1): 601-608.

62. Malo JL, Chrétien P, McCants M, Lehrer S. Detection of snow-crab antigens by air sampling of a snow-crab production plant. Clin Exp Allergy 1997; $27:$ 75-78.

63. Bang B, Aasmoe L, Aardal L et al. Feeling cold at work increases the risk of symptoms from muscle, skin and airways in seafood industry workers. Am J Ind Med 2005; 47: 65-71.

64. Lucas D, Loddé B, Pougnet RP, Dewitte JD, Jegaden D. Evaluation of the sensitisation to grains and its pulmonary impact in employees of the port of Brest silos. Int Marit Health 2013; 64: 18-23.

65. Baur X, Budnik LT, Zhao Z et al. Health risk in international container and bulk cargo transport due to volatile toxic compounds. J Occup Med Toxicol 2015; 10: 19.

66. Bromométhane. Fiche toxicologique $\mathrm{N}^{\circ} 67$. INRS 2007. www.inrs. $\mathrm{fr} /$ publications/bdd/fichetox/fiche.html?refINRS=FICHETOX_67

67. Hydrogen phosphide. Fiche toxicologique $N^{\circ} 179$. INRS 2008. www.inrs.fr/publications/bdd/fichetox/fiche.html?refINRS =FICHETOX_179.

68. Rosenberg N. Allergie respiratoire professionnelle aux produits phytosanitaires. Doc Médecin du Travail 2010; 124: 471-482. 